\title{
The Effectiveness of Direct Instructional Learning Model in Assessment Process Course and Learning Outcomes
}

\author{
Subandi \\ Universitas Negeri Surabaya \\ Surabaya, Indonesia \\ subandi@unesa.ac.id \\ Cicik Arista \\ Universitas Negeri Surabaya \\ Surabaya, Indonesia \\ cicikarista@unesa.ac.id
}

\author{
Galih Wibisono \\ Universitas Negeri Surabaya \\ Surabaya, Indonesia \\ galihwibisono@mhs.unesa.ac.id \\ Muhammad Farhan Masrur \\ Universitas Negeri Surabaya \\ Surabaya, Indonesia \\ fubandeng_feilun27@unesa.ac.id
}

\begin{abstract}
Pedagogical competence supports successful learning, however, the ability to arrange the assessment tools as one of the learning materials that be implemented by teacher and preservice Mandarin Language teacher still becomes underlying issues today. The reality shows the expertise of material substance has been mastered, but the teaching theories are often neglected. Direct instructional model as one of the teaching models had been examined, and it results assisted students in understanding the learning materials. It was proved by knowing students' skill in arranging an assessment that were guidelines of the questions and exercises. This model gave students an opportunity for direct experience in the process of making assessment tools. The direct experience that students gained were saved in memory. It continued to the process of settling on the brain and become a semipermanent knowledge. Then, it also assisted students easily absorb the information. Based on the results of this study, direct instructional model was assumed to be one of the alternative teaching model choices. It could be used in productive courses which had purposes in arranging learning materials. Therefore, this teaching model referred to improve the students' ability and skill, and in the end of the learning process students were demanded to produce learning material more than examining the cognitive skill.
\end{abstract}

Keywords-Constructing; direct experience; direct instructional model, systematic thinking; linked concept

\section{INTRODUCTION}

Assessment is one of learning phases that should be done by teacher in the learning process. The results of the assessment will be used as focus consideration before the practitioners or teachers deciding for final result [1]. It means the results of the assessment has a crucial role in deciding students' learning final result. Thus, teachers are demanded to have good teaching competence in the process of assessment, choose and decide the assessment tools, even develop and arrange the appropriate assessment tools. It is because the use of appropriate assessment tools with the purpose of assessment, and type of assessment will affect the results of assessment validation. The ability of teachers to develop and arrange the assessment tools will influence on organizing and variating the assessment tools skill to be more various and innovative. It is because when the assessment tools have those elements, it will influence on increasing the students' motivation and learning outcomes [2][3]. Besides, the implementation of the process of learning assessment guides students' skill to arrange the assessment tools, it also needs to emphasize the aspects of the ability arranging assessment instrument. It is because the cognitive aspects are not only aspect to focus on, but it is needed to focus on the psychomotor aspect as an indicator to create the students' positive behavior through the learning process.

Learning as a form of activity implanting a scientific concept that functions as a source of changes in behavior, attitudes, and mindsets of students [4]. It means through the educational learning process, the students are helped to change and shape their characters that reflect in how their competence increased. It is supported by [5] and [6], they explained the learning process is a process of behavior change through interactions between individuals and the environment where they live and as a process of a series of activities that sustainable, planned, gradual, rotating, balanced and integrated. The changing behavior means the condition where students were not able to do something become capable of something, and they can communicate the results of the changes to those involved in as the form of implementation in the social aspect. Those statements were in line with Aljunied \& Poon [7] statement, they stated education must ultimately be able to bring students to the ability to interact socially, communicate socially, have attention to attitudes and behavior and lead to an easier and more meaningful life. Furthermore, to bring students to the ability to interact socially with the accuracy of the application of learning models is one of the most important factors, researchers have tested the direct instructional model as a solution.

The direct instructional model is a learning model that is more directing students to build understanding through direct experience in the form of practices or direct demonstrations. Trianto [8] said, the direct instructional model is one of the teachings specifically designed to support students learning 
processes related to declarative knowledge and well-structured procedural knowledge that can be taught with a pattern of gradual, step-by-step activities (2011: 12). In this study, the direct instructional model is applied to students of Mandarin Language Education study program, Faculty of Languages and Arts, UNESA, class of 2016/2017 who is taking the course Assessment Process and Learning Outcomes in order to form knowledge and skills compile assessment tools as well as to prepare students who will carry out real teaching/teaching practices at school.

Based on the results of the pre-test at an early stage, students had not understood correctly both theoretical knowledge and skills related to the mechanism of preparation of assessment tools. The assessment tool is one of the learning instruments that have a very vital and fundamental role especially for prospective teachers and/or beginner teachers [9]. The rationale used is related to the use of direct learning models because, given the characteristics of this subject, it requires students to produce a product in the form of assessment tools (lattice questions and question scripts) as the final target of learning, the chosen model strategy and considered appropriate is the direct instructional model. It is because this learning model emphasizes aspects of demonstration/direct practice by students while aspects of theoretical knowledge are used as an introduction and strengthened when students practice the preparation of tools and/or when making presentations and discussions.

Providing more opportunities for students to experience directly compiling assessment tools, students are proven to be able to find information taught in real terms. The impact can help facilitate students in constructing the process of understanding. As stated Glogger and Naeimi [10][11] with direct instructional models students can arrange and design their understanding where this aspect becomes more important in the process of understanding a concept. Furthermore, Kozloff and Oladayo [12][13] stated, direct instructional models could stimulate students to play an active role both in the process of providing ideas in terms of responding to criticism based on their experience. It means through the direct instructional model students tend to be more active so that they give the freedom to design and construct their understanding processes according to what they experienced. This is because one of the goals of organizing the educational process is to develop students' thinking abilities (in this case students) on a concept of knowledge (cognitive aspects) but, it must also be able to realize (psychomotor aspects) the concept into the form more concrete results.

\section{Direct Instructional Model}

This The Direct instructional model is learning models that provide students direct experience through modeling, practical works, demonstrations, and presentations to help facilitate the process of understanding students of a concept. Direct instructional learning models are designed to introduce students to subjects to build interest, arouse curiosity, and stimulate them to think independently to find an understanding of certain concepts and/or skills independently as well [5]. Furthermore Stevick [14] stated, the direct instructional learning model was developed specifically to improve the learning process of students in terms of understanding the knowledge and explaining it in full based on procedural knowledge and declarative knowledge taught gradually. It means the direct learning model is one of the teaching models specifically designed to develop student learning about procedural knowledge and declarative knowledge, well-structured and can be learned gradually or step by step. The direct instructional learning model aims to provide a gradual direction of the process of understanding a concept for students. Therefore, teachers who want to use the direct instructional learning model must identify learning objectives, material structure, and basic skills to be taught. Furthermore, basic knowledge that is more theoretical, it is conveyed to students and the teacher provides modeling or demonstration, provides the opportunity for students to try to practice applying the concepts/skills that have been learned and provide feedback.

Direct instructional learning models are used to describe learning models with face-to-face contexts and have been designed to improve the behavior of students sought by teachers. The aims are to monitor and control the attention and participation of students in the classroom [15]. This opinion suggests that the behavior of students and their changes as long as students are in the learning process in class is an aspect that is used as a focus by the direct learning model. It means prioritizing aspects of the process especially those concerning the active role and behavior of students during the learning process and not just the outcome of learning. Therefore, students are required to learn basic skill and obtain information that can be taught step by step. The direct instructional learning model also provides an opportunity for students to learn how to selectively observe, remember, and imitate what is modeled by the teacher. Besides, the direct learning model also prioritizes a declarative approach with a focus on the process of learning concepts and motor skills to produce a more interesting and structured learning atmosphere. Lee and Darch [16] stated students will be able and responsive to every symptom and phenomenon and more easily convey arguments/opinions as a result of the authority to manage and manage the concept of understanding.

Furthermore, Schwartz et al [17] said having the authority to regulate their psychological impact on how students grew. They will have the strength and ability so that the impact of psychological pressure does not occur. The purpose of the two quotations above is, that the direct learning model has a role not only to one aspect of the learning target but also has a positive impact on the psychological condition of students. Psychological conditions of students have very significant relevance to the smooth implementation of the learning process and have a higher level of likelihood of the achievement of learning objectives.

Learning models that give learners the freedom to manage their learning processes are considered more attractive because, students will be relatively more active in carrying out relevant activities to build knowledge, skills, and determination related to learning targets and objectives. This opinion is reinforced Magliaro et al [15] opinions, Mesquita [18], and [19] Metzler [19] which outlines the basic objective of the direct instructional learning model is, to provide direct experience to students so that in the next stage they can carry out independently by using the experience gained by experiencing themselves. The emphasis of the opinion above is, that the human brain is more sensitive to real and concrete stimuli such as events or events that are experienced directly so that, it will be easier to express it again 
than things that are abstract like a concept. This is because, things that are concrete and real that can be enjoyed by the sense of sight, are easier to remember in the memory of the human brain. In contrast, words where the physical manifestation is invisible and more abstract in consequence, it is more difficult to store in the memory of the human brain.

The experience gained directly by way of doing/undergoing it directly by itself conforms to the mechanism of action of the human brain. The human brain will be more interested and respond will then be remembered for all objects that are interesting sympathetic and concrete/real. By using concrete experience and knowledge, it can attract students' interest so that the direct instructional learning model can meet the tastes and needs of the human brain character. It is because this conformity factor that stimulates the human brain to receive and store objects/data and ultimately be able to remember and express again.

\section{Performance Assessment}

Performance assessment or authentic assessment refers to a test requiring students' performance ability or assessment of psychomotor aspects. It means that performance assessment emphasizes the ability or skills of students to develop a product that is used as the final target in learning. According to Subali and Stufflebeam [2] [20] said, performance assessment is an assessment that focuses on involving mental processes or thinking processes of students to produce a product. Based on their opinion, performance assessment requires the stages of the process of observation of students' activities. It is because performance assessment also needs to look at the aspects of students' understanding of a concept further how they can apply it to performance to produce a product. In this research, the concept of performance assessment is used to observe and assess how students understand the assessment concept, the instruments assessment concept, the concept and mechanism of assessment tools, and how they can actualize these concepts into a product in the form of assessment tools, namely the assessment questions and question scripts.

Therefore, student performance is seen starting from the aspects of the accuracy of the stages of product preparation, product results, product presentation, as well as discussion and discussion in order to solve problems. Besides, students' performance is also assessed through observations. Subali and Anderson [2] [21] explained that the observation technique would be suitable if the performance was carried out in the form of assigning something through a standard or procedural procedure. Then, the observation techniques used to monitor the improvement of students' learning results through a task, were arranging the indicators of questions and questions script based on mechanism and procedure that have been given before. From the results of observation, it obtained the students' understanding of information in conceptual aspects. Also, they were able to do their good performance or they were difficult to understand the information while they did performance. Performance observations are measured by rating of rubrics score.

\section{MethodS}

\section{A. Participant}

The researcher adopted a quasi-experimental research design in conducting this study, to determine the effects of direct instructional models on the ability of students to compile assessment tools in the form of questions and question scripts. The randomized, experimental pre-test/post-test control design was adopted. Participants in this study were 28 students, in the six semesters (University students in the academic year of 2016) in Mandarin Language Education class A program, Mandarin department of UNESA. They were programming or taking the Assessment Process and Learning Outcomes subject and are divided into 6 big groups. This research was done within one semester (15 meetings) with the following classification: 4 meetings of discussing the theoretical concepts, 3 meetings of techniques and procedures for elaborating $\mathrm{KD}$ into indicators, assigning material based on indicators, determining the form of questions, 2 meetings of grids preparation process, and 6 final meetings of presenting, dictation and reflecting the project. The data of this study were the pre-test and post-test scores. First, it included the aspects of the accuracy of the elaboration and linearity of KD to the indicators, the suitability of the indicators with the material, the suitability of the material with the form of the questions. Second, it included the aspects of the student's performance/performance as measured by students' score based on the rubric of performance. It would be continued by analyzing the data through statistical calculations using the Ttest formula [22] [23].

\section{B. Data Analysis}

This This research is qualitative research. It was because the main data was students' scores which were calculated using the t-test analysis formula. Furthermore, the results of the analysis were described in the form of words to explain the results. The complete results of the study are described as follows.

\section{RESUltS AND DisCUSSION}

\section{A. Results}

\section{Pre-Test}

The pre-test was conducted at the first meeting with the aim to find out the initial ability possessed by students to develop assessment tools before the material is taught. Table 1.1 below is the recapitulation of the average value of students and the standard deviation calculated through the t-test formula.

Table 1.1. The Result of average value and standard deviation of students

\begin{tabular}{|c|c|c|}
\hline Activity & Mean & Standard deviation \\
\hline Pre-test & 37,56 & 6,41 \\
\hline
\end{tabular}

After the pre-test was applied, the researchers carried out the treatment in the form of providing material through the learning process by the syntax of the direct instructional learning model. In the learning process of educators, in this case, the researchers demonstrated their knowledge and skills in compiling assessment tools in a coherent/systematic manner step by step and correctly. 
The next phase, researchers provided opportunities for students to implement their knowledge in the form of preparation of assessment tools. At that time, researchers were not only observing, but also providing assistance and guidance. From this process, the researchers gained information whether the students did the assignment correctly or not. When the information did not clear yet, immediately the researchers gave feedback orally in front of class in order to inform all students in the class.

In the last phase, the researcher prepared further assistance and guidance according to the predetermined stages. In this phase, more attention was focused on the phase of applying more complex concepts and continuing the discussion as feedback which would be used by students as a basis for improvement. The improvement process was given in the form of assignments because the results of this improvement process are used as part of the post-test.

\section{Post Test}

The implementation of the post-test was carried out with the aim to find out the student learning outcomes after receiving the material as well as coaching and mentoring during the learning process with the direct instructional learning model in progress. The post-test results are a conclusion of the ability of the final results of student learning in the mastery of the preparation of assessment tools after following the learning process with the direct instruction learning model. The results of post-test that students gained were showed in table 1.2 as follows.

Table 1.2. The Results of Average Value and Standard Deviation

\begin{tabular}{|l|l|l|}
\hline Activity & Mean & Standard Deviation \\
\hline Post-test & 81,21 & 13,49 \\
\hline
\end{tabular}

If you see the results of an average value of 81.21 that had been obtained by students, it could be concluded that the knowledge and competence of students had increased very significantly and could be said to have been completed. It is because there was a difference between the results of the pre-test mean value and the post-test average value of 37.56 compared to 81.21 where there is a very significant increase. The increment in the average value of this post-test occurred as a result of providing treatment that is the use of direct instruction learning models during the learning process carried out.

\section{B. Discussion}

In the pre-test, all the students had difficulties in answering the questions, whether theoretical conceptual questions or preparation of the assessment tools. This information is supported by pre-test results. That was distant from the normative standard of eligibility. To help construct students 'understanding, researchers immediately prepare the syntax of direct instructional learning models as a solution to students difficulties. Although the students were noisy and confuse with the direct instructional model in the beginning because they did not know before, they became more understand and conducive when they had explained the procedures, goals, and benefits of this learning model.

To assist students stored their understanding, at the end of the meeting, they were given homework and submitted in the following week. Furthermore, the result of their assignments was evaluated by researchers. They gave the score and feedback based on the students' assessment rubrics as their basis improvement. From the results of the assignment, especially in the case of the compilation of questions, it was found that three errors with the highest frequency of occurrence, namely the elaboration of KD to indicators and assessment objectives, from indicators to test material, and from material to the determination of the form of questions. The researcher provided input and suggestions in the form of notes, comments, and or suggestions directly on the draft assignment that was examined, then the draft assignment was returned to students in the following week. After the draft was returned, the researcher explained especially on errors that were of high frequency and were experienced by most students and errors that were considered fatal.

The next phase, the students revised directly, and the researchers were guiding one by one to monitor and assist them, and especially who needed help. Those conditions were continued as what the researcher arranged in the learning schedule. The results of the draft revision did not submit to the researcher, but it would be collected with the next assignment. After the assignments and guidance phase was done, the whole assignments were collected in the one file to prepare the next phase. That was the presentation and discussion of the final results. In this phase, the direct instructional learning model had been going well and smoothly.

During the presentation phase, the revised draft of the assignments was collected to the researchers for the final results. Thus, when students presented, the researchers were not only observed the presentation activities but also evaluated the draft assignment. The results of the evaluation of the draft had not found any fatal mistakes, but feedback were noted for improvement. In the presentation moments, students played an active role. The presenters were well-prepared so that the presentation was a success. It was because how the presenter did the material substitution well-prepared, systematically, and continuously so that the presentation flow was easy to follow and understand. Students who acted as participants also showed enthusiasm and excellent activities. This could be seen when the discussion session was started. They were encouraged to ask questions or give suggestions. Furthermore, it was not all questions could not be answered, because of time limitation. Therefore, the students who wanted to give some suggestions were demanded to write down.

From the competency aspect, the presenters also showed the impression of mastery of the material and strategy. All questions could be answered smoothly, coherently, and in detail. This condition proved that the presenters mastered the material. Meanwhile, to respond to the suggestions and comments from the participants, the presenters did not immediately decide to accept or reject, but continued to be addressed through the analysis and identification process. Hopefully, participants who provided suggestions and comment got feedback by knowing how their reasons were accepted or rejected. From the two processes, only the presenters made a decision whether the suggestions and comments were accepted or rejected. 
The results of the average post-test score of students were 81.21 and results of t-test showed after giving the students direct instructional model students learning outcomes related with the preparation of the assessment tools and questions guidelines could be said significantly complete. Those results were supported by the results of this $\mathrm{t}$-count $=2.07$ with degrees of freedom $\mathrm{dk}=\mathrm{n}-1=27-1=26, \mathrm{a}=0.06$ obtained table $=1.73$. Therefore, t-count> t-table was $2.07>1,73$ so that the hypothesis is accepted. It means that students learning outcomes on the course of the Assessment Process and Learning Outcomes of students of the 2016/2017 Mandarin Language Study Program in the sixth semester were significantly completed using the direct instructional learning model.

Those results proved the suitability and linearity of the theoretical concepts used in this study. The involvement of the students in the lecture process especially at the stage of the demonstration process and the preparation of assessment tools directly have a positive impact. Those were increasing the aspects of motivation, activeness and excitement of students to be directly involved in the learning process. The direct experience gave students a positive contribution in the construction process of understanding to be more meaningful. Consequently, the students trace the answers by themselves and they got a solution to the problem that appeared during the learning process.

\section{CONCLUSION}

The implementation of direct instructional learning model assists students to gain the real and authentic experience through guiding them on demonstrations and direct practical works independently. Direct experience shapes learners' more concrete and tangible understandings which ultimately form synergistic knowledge and skills to produce a product that is targeted at the basic competencies in the form of assessment tools, namely, the indicators of questions and question scripts. Knowledge and skills of students are built through stages of a tiered and sequential process to help facilitate the process of constructing student understanding. Direct experience gained during demonstrations and practical works as an answer and solution to the problems faced and at the same time as a reinforcing component of students' understanding of the concepts of scientific priority that have been received at an early stage. This conclusion is strengthened by the results of the t-test which showed that the final results proved that the hypothesis was accepted, which means that the direct instructional learning model positively contributes to the improvement of knowledge and skills of students of the 2016/2017 UNESA Mandarin Language Study Program class $A$ in the sixth semester in compiling assessment tools in the form of indicators of questions and question scripts.

\section{REFERENCES}

[1] B. Nurgiyantoro, Penilaian Pembelajaran Bahasa Berbasis Kompetensi Yogyakarta: BPFE-Yogyakarta, 2010.

[2] B. Subali, Evaluasi Pembelajaran (Proses dan Produk), Makalah Workshop Evaluasi bagi Dosen Universitas Muhammadiyah Purwokerto. 23 Agustus 2014.
[3] J. Grisham-Brown, R. Hallam, and R. Brookshire, "Using Authentic Assessment to Evidence Children's Progress Toward Early Learning Standarts," Early Childhood Education Journal., vol. 34, no. 9. pp. 45-51, 2006.

[4] W. Sanjaya, Strategi Pembelajaran Berorientasi Standar Proses Pendidikan. Jakarta: Kencana, 2007.

[5] Subandi dkk, "The Implementation of Mind Mapping Technique to Improve Mandarin Students' Systematic Thinking Skills", In Advances in Social Science, Education and Humanities Researce. Atlantis Press, vol 222, pp.390-395. 2018.

[6] W. Iskandar and D. Sunendar, Strategi Belajar Bahasa. Bandung: Remaja Rosdakarya Offset. 2009.

[7] M. Aljunied, \& K. P. Kenneth, Thinking and Learning Characteristics, In: Poon, Keneneth K. Educating Students With Autism Spectrum Disorders -Making Schools Meaningful-. Jurong Singapore: Pearson, 2009.

[8] M. Trianto, Model pembelajaran inovatif-progresif: konsep, landasan dan implementasinya pada kurikulum tingkat satuan pendidik, (KTSP), Kencana Prenada Media Group, 2011.

[9] L. Gatlin, and S. Jacob, "Standards-based Digital PortFolios: A Cpmponent of Authentic Assessment for Preservice Teachers", Action in Teacher Education, vol 23, no 4, pp. 28-34, 2002.

[10] I. Glogger-Frey, G. Kartarina, and R. Alexander, "Learning from Direct Instruction: Best Prepared by Several Self-Regulated or Guided Invention Activities?", Elsevier, Learning and Instruction. pp. 1-10, 2016

[11] M. Naeimi, and T. Chow Voon Foo, "Vocabulary acquisition through direct and indirect learning strategies. English Language Teaching", vol 8, no.10, pp. 140-150, 2015.

[12] M. A. Kozloff, and L. LaNunziate, Direct Instruction in Education, University of North Carolina at Wilmington. January, pp. 1-26, 1999.

[13] O.T. Oladayo, and C.F. Oladayo, "Effects of Direct and Indirect Instructional Strategies on Students' Achievement in Mathematics", An International Multidisciplinary Journal., Serial No. 27, October 2012, vol. 6, no.4, pp. 349-361, 2012.

[14] E. Stevick, Memory, meaning, and method. Rowley, MA: Newbury House, 1976

[15] S.G. Magliaro, B.B. Lockee, and B. John K, "Direct Instruction Revisited: A Key Model for Instructional Technology. In Educational Technology Research and Development”, pp. 41-55, January 2005.

[16] C. Darch, R. Gersten, and R. Taylor, "Evaluation of Williamsburg Country Direct Instruction Program: Factors Leading to Success in Rural Elementary Programs", Research in Rural Education., vol 4 , pp. 111-118, 1987.

[17] D.L. Schwartz, C.C. Chase, M. A. Oppezzo, and D.B. Chin, "Practicing Versus Inventing with Contrasting Cases: The Effects of Telling First on Learning and Transfer", Journal of Educational Psycology." 103. pp. 759-775. 2011.

[18] I. Mesquita, and C. Patricia, "The Value of Indirect Teaching Strategies in Enhancing Student-Coaches", Learning Engagement Journal of Sports Science and Medicine., pp. 657-668, 2015.

[19] M. Metzler, Instructional Models for Physical Education, Allyn and Bacon, Needham Heights, 2000.

[20] D.L. Stufflebeam, Education Evaluation and Decision Making Illinois: F.E. Peachock Publisher. Inc, 1977.

[21] O.W. Anderson, and D.R. Krathwohl, A taxonomy for Learning, Teaching, and Assessing: A Revision of Bloom's Taxonomy of Educational Objectives. New York: Longman, 2001.

[22] Sugiyono, Metode Penelitian Kuantitatif, Kualitatif, dan Kombinasi. Bandung: ALFABETA, 2011.

[23] S. Arikunto, Dasar-Dasar Evaluasi Pendidikan. Jakarta: Bumi Aksara, 2009. 